\title{
The nature of inheritance of selection attributes and realization of the potential productivity of rabbits of breed Poltavske sriblo
}

\author{
Bashchenko M. ${ }^{1}$, Boyko O. ${ }^{2}$, Gonchar $0{ }^{3}$, Havrysh $0 .{ }^{4}$, Sotnichenko Yu. ${ }^{5}$ \\ Cherkasy Research Station of Biological Resources of NAAS \\ 76 Pasterivska Str., Cherkasy, 18036, Ukraine \\ e-mail: bioresurs.ck@ukr.net; \\ ORCID: ${ }^{1} 0000-0002-2872-7055,{ }^{2} 0000-0002-7227-4970,{ }^{3} 0000-0003-2269-9767$, \\ ${ }^{4} 0000-0002-8632-6508,{ }^{5} 0000-0003-2520-298 X$
}

\begin{abstract}
Goal. To find out the nature of inheritance of selection attributes and the level of realization of the potential productivity of rabbits of breed Poltavske sriblo. Methods. The study was conducted based on the research rabbit farm of Cherkasy research station of bioresources of NAAS on the livestock of rabbits of breed Poltavske sriblo. To achieve the goal group of animals was formed and analyzed in terms of several generations. Results. The data indicate that for pure breeding, because of the small variability of the studied signs, a probable correlation was fixed in values of the width of the loin ( $r=0.26 ; P>0.99)$. The analysis of the index of the phenotypic correlation between selection attributes in the output of livestock and progeny indicates a direct or inverse relationship between the signs $(-0.10 \ldots .10, P<0.95)$. The coefficients of inheritance of selection attributes have also been found reliable in terms of live weight at the age of 120 days and an indicator of the width of the waist in adults ( $\mathrm{h} 2=0.27-0.52$; $P>0.99-0.999$ ). For the rest of the studied indicators ratios have been established, which amounted to 0.19 and 0.27 , but they were not statistically significant $(P<0.95)$. Research on the productivity of rabbits showed that in the created population the degree of implementation of selection-genetic potential of productivity was $93.7-99.9 \%$ depending on the examined attribute. That value was maximal in terms of the width of the back (99.86\%). Conclusions. The results of the study of the exterior indicators of the body and live weight of rabbits of the source generation and posterity have witnessed a high level of realization of the genetic potential of animals in the created population - 93.7-99.9\% depending on the studied attribute. The coefficients of inheritance of selection attributes were significant in terms of live weight at the age of 120 days and an indicator of the width of the waist in adults $(\mathrm{h} 2=0.27-0.52 ; \mathrm{P}>0.99-0.999)$, which provides the prerequisites for further breeding activities to enhance meat productivity.
\end{abstract}

Key words: parts of the body, breeding, variability of attributes, genetic potential, population.

DOI: https://doi.org/10.31073/agrovisnyk202006-04

One of the most widespread domestic breeds of rabbits in Ukraine is the Poltava silver breed, or as it is called this breed "silver". Bred in the animal farm "Petrovsky" of Poltava region in 1952, this breed took its place and for a long time was grown in the yards of peasants and klepherms of different farms both in our country and in other republics of the USSR. The biological characteristics of this breed make it possible to obtain animals with a live weight of $4-5 \mathrm{~kg}$, and the combined direction of productivity provided not only dietary meat, but also skim raw materials that were in high demand [1-3].

Nowadays, rabbit breeding has moved to an intensive industrial form of farming, which has affected the change of priorities in the selection of breeds for breeding, primarily for meat. This provided the preconditions for increasing the share in the breed

the composition of meat-producing animals - California and New Zealand white breeds [4-6]. However, a significant proportion of rabbit meat producers in Ukraine are still concentrated in the private sector and use the genetic resources of domestic breeds, which necessitates

research to increase the meat productivity of rabbits [7-10]. Purebred rabbit breeding requires the rabbit breeder to constantly analyze the performance of families and lines using the latest methods for assessing the breeding value of animals, taking into account the economic component, which determines the profitability of the industry [5, 11].

A systematic approach in the optimization of breeding programs and the search for optimal animal selection options leads to increased efficiency of the breeding process [2, 11].

Analysis of recent research and publications. The study of the productivity of rabbits is devoted to the work of I.S. Vakulenka, B.B. Myrosia, I.S. Luchyna, G.A. Kotsiubenko, E.A. Shevchenko, V.I. Baly, etc.

The purpose of the work was to find out the nature of the inheritance of breeding traits and the level of realization of the potential productivity of the Poltava silver rabbits.

The object of research is the process of formation of productivity indicators in rabbits of Poltava silver breed in the context of generations, the nature of inheritance of selection traits and the degree of realization of genetic potential of productivity.

Materials and methods of research. The study was conducted at the rabbit farm of the Cherkassy research station bioresources NAAS of Ukraine. Poltava silver (PS) rabbits breeders and breeders and their offspring obtained with purebred breeding (Table 1) were used for the experiment. 
1. Scheme of the experiment

\begin{tabular}{|c|c|c|c|}
\hline \multicolumn{2}{|c|}{ Parental generation } & \multirow{2}{*}{ Posterity } & \multirow{2}{*}{ The investigated signs } \\
\hline Male & female & & \\
\hline$P S(n=10)$ & $\begin{array}{c}P S \\
(n=50)\end{array}$ & $\begin{array}{l}P S, F 1 \\
(n=100)\end{array}$ & $\begin{array}{l}\text { - straight body length, } \mathrm{cm} ; \\
\text { - body girth, } \mathrm{cm} \text {; } \\
\text { - body index,\% } \\
\text { - live weight at the age of } 120 \text { days, g; } \\
\text { - width across, cm; } \\
\text { - fertility of females }\end{array}$ \\
\hline
\end{tabular}

Studies of these breeding traits were performed according to the conventional method in rabbit breeding [12].

The rabbits body index was determined by the formula:

Body index $=(\text { body girth, } \mathrm{cm} / \text { straight body length, } \mathrm{cm})^{*} 100$

On the basis of the average values for the studied indicators and the breeding effect, the target standard for each quantitative criterion was calculated by the formula:

$$
S_{t}=x+\Delta
$$

where, $x$ - mean of the trait in the population; $\Delta$ - expected breeding effect on the basis of the next generation.

The expected breeding effect was determined by the following formula:

$$
\Delta=S d^{*} h^{2}
$$

where, Sd - breeding differential, according to the test trait; $\mathrm{h} 2$ - coefficient of heredity of the trait.

The heredity of breeding-genetic traits of rabbits was determined by methods of doubling correlation coefficients by the mother-daughter path:.

$$
h^{2}=2^{*} r
$$

where, $r$ - correlation coefficient between the respective performance indicators [13].

The obtained research materials were processed by the methods of mathematical statistics by means of the software package "Statistica - 12.1" and Excel (Microsoft Office 2010) in a Windows environment on a computer based on the algorithms of N.A. Plohinsky [14].

Research results. By taking measurements of body sex and live weight indices of both parental and offspring obtained from purebred breeding, it was established that the animals involved in reproduction were characterized

\begin{tabular}{|c|c|c|c|c|c|}
\hline Traits & $N$ & $M \pm S . E$. & $\lim$ & Std.Dev. & C.V., \% \\
\hline \multicolumn{6}{|c|}{ Male } \\
\hline Straight body length, $\mathrm{cm}$ & 10 & $63,4 \pm 0,21^{*}$ & $62-65$ & 2,1 & 3,30 \\
\hline Body girth, $\mathrm{cm}$ & 10 & $32,5 \pm 0,13^{*}$ & $31-34$ & 1,3 & 3,98 \\
\hline Body index, $\%$ & 10 & $51,26 \pm 0,04^{*}$ & $50-51$ & 0,4 & 0,75 \\
\hline Live weight, $g$ & 10 & $5327,6 \pm 15,91^{*}$ & $5200-5400$ & 163,1 & 2,90 \\
\hline Width across, $\mathrm{cm}$ & 10 & $5,8 \pm 0,01$ & $5,5-6,2$ & 0,1 & 2,45 \\
\hline \multicolumn{6}{|c|}{ Female } \\
\hline Straight body length, $\mathrm{cm}$ & 50 & $54,6 \pm 0,26$ & $52-60$ & 2,7 & 4,87 \\
\hline Body girth, $\mathrm{cm}$ & 50 & $25,7 \pm 0,20$ & $25-30$ & 2,0 & 7,48 \\
\hline Body index, $\%$ & 50 & $47,1 \pm 0,26$ & $46-51$ & 2,7 & 5,52 \\
\hline $\begin{array}{l}\text { Live weight at the age of } 120 \\
\text { days, } g\end{array}$ & 50 & $4461,9 \pm 20,54$ & $4200-4800$ & 210,5 & 4,72 \\
\hline Width across, $\mathrm{cm}$ & 50 & $6,1 \pm 0,02^{*}$ & $5,9-6,2$ & 0,2 & 3,85 \\
\hline Fertility & 50 & $7,6 \pm 0,19$ & $4-11$ & 2,0 & 25,9 \\
\hline
\end{tabular}
by large size and characteristic breed characteristics of the body parameters (Table 2).

\section{Characteristics of the parental generation of Poltava silver rabbit breed}

Note: ${ }^{*}-P>0.999$ 
The length of the body of the beetles and fruit plants varied within $54.6 \mathrm{~cm}$ and $63.4 \mathrm{~cm}$, respectively, having a low level of variation of the characteristic (C.V. $=3.30-4.87 \%$ ). The breast circumference index also had low variability and was $32.5 \mathrm{~cm}$ for the fetuses, $25.7 \mathrm{~cm}$ for the rabbits, respectively (C.V. $=3.98-7.48 \%$ ).

Indicators of live weight ranged from $4200-4800 \mathrm{~g}$ for females and $5200-5400 \mathrm{~g}$ for brooders. Low values of the coefficient of variation for these indicators indicate the consolidation of the studied population (C.V. $=2.6-3.3 \%$ ). The index that most characterizes the direction of productivity, namely the body mass index, varied within $46-51 \%$ and averaged $51.3 \%$ for males and $47.1 \%$ for rabbits, which is typical for rabbit meat rabbits breed. This indicator characterizes the direction of productivity of the breed of rabbits, the higher its value, the higher the indicators of meat production.

It is also worth noting that the males outweighed the females on all the traits studied, except for the width of the waist, by which the predominance of the rabbits was $0.3 \mathrm{~cm}(P>0.999)$.

The level of fertility of the skeletons during the study was 7.6 goals. and had an average level of variation of sign (SV $=25.9 \%)$, which also indicates a high level of reproductive capacity of animals of this breed.

As part of the study, the performance of rabbits of the offspring of the original generation of rabbits was analyzed, and the results of the study of breeding traits are shown in Table 3.

\section{Descriptive measure performance of the posterities}

\begin{tabular}{|l|r|c|c|c|c|}
\hline \multicolumn{1}{|c|}{ Traits } & $N$ & M S.E. & lim & Std.Dev. & C.V., \% \\
\hline Straight body length, cm & 100 & $52,1 \pm 0,52$ & $44-62$ & 3,0 & 5,42 \\
\hline Body girth, cm & 100 & $23,6 \pm 0,11$ & $22-31$ & 1,6 & 6,03 \\
\hline Body index,\% & 100 & $45,3 \pm 1,78$ & $43-53$ & 3,2 & 6,27 \\
\hline Live weight at the age of 120 days, $\mathrm{g}$ & 100 & $4298,6 \pm 41,13$ & $4000-4800$ & 421,4 & 9,80 \\
\hline Width across, cm & 100 & $5,9 \pm 0,30$ & $5-7$ & 0,3 & 5,96 \\
\hline Fertility, goals & 100 & $7,2 \pm 0,32$ & $3-10$ & 1,8 & 27,80 \\
\hline
\end{tabular}

The data show that the average value of the length of the body for the offspring was $52.1 \mathrm{~cm}$, with the level of variation was low $5.42 \%$. Body girth was in the range of $22-31 \mathrm{~cm}$, the average value was $23.6 \mathrm{~cm}$, which is 2.1 $\mathrm{cm}$ probably lower compared to the same indicator of mothers ( $P>0.999)$.

Body index female first-generation rabbits were in the range of $43-53 \%$, but its average for daughters was slightly lower than that of mothers and was $45.3 \%$, but this difference is not statistically significant. Also found that first-generation rabbits were $163.3 \mathrm{~g}$ below the value of live weight compared to the original generation $(P>0.999)$. The level of fertility of the skeletons had an average level of variation of the sign $(C . V .=27.8 \%)$ and made 7.2 goals, which is 0.4 goals. lower than the parental rabbit fertility rate. The difference in performance of mothers and daughters makes it necessary to investigate the nature of the inheritance of traits and to establish relationships between them to further understand the course of the breeding process in the population created.

The data indicate that in purebred breeding, given the insignificant variability of the studied traits, a correlation in the index of the width of the waist $(r=0.26, P>0.99)$ was likely (Table 4).

\section{Correlations and heredity of breeding traits in rabbits}

\begin{tabular}{|l|c|c|c|c|}
\hline \multicolumn{1}{|c|}{ Correlating signs } & $r \pm$ S.E. & $t_{r}$ & $h^{2} \pm S . E$. & $t_{h}{ }^{2}$ \\
\hline Straight body length, $\mathrm{cm}$ & $0,10 \pm 0,012$ & 0,98 & $0,19 \pm 0,083$ & 0,67 \\
\hline Body girth, $\mathrm{cm}$ & $0,13 \pm 0,020$ & 1,40 & $0,27 \pm 0,041$ & 0,68 \\
\hline Body index,\% & $-0,10 \pm 0,037$ & 0,47 & $0,20 \pm 0,074$ & 0,33 \\
\hline Live weight at the age of 120 days, g & $-0,13 \pm 0,013$ & 1,39 & $0,27 \pm 0,026$ & 10,25 \\
\hline Width across, cm & $0,26 \pm 0,538$ & 2,75 & $0,52 \pm 0,076$ & 2,48 \\
\hline Fertility, goals & $0,12 \pm 0,074$ & 1,17 & $0,21 \pm 0,032$ & 0,91 \\
\hline
\end{tabular}

Analysis of the phenotypic correlation between breeding traits in the source population and offspring indicates a direct or inverse relationship between traits $(-0.10 \ldots 0.10, \mathrm{P}<0.95)$.

The calculated inheritance coefficients of breeding traits were also found to be more probable in terms of live weight at the age of 120 days and in width in adult animals $\left(h^{2}=0.27-0.52, P>0.99 \ldots 0.999\right)$. According to the rest of the studied indicators, the established coefficients were $0.19-0.27$, but were not statistically significant $(P<0.95)$.

The study of rabbit productivity, allows to state that in the created population the degree of realization of breeding and genetic potential of productivity is $93.7-99.9 \%$ depending on the trait that was investigated (Table 5). The maximum value is set at a width of $99.8 \%$. 


\section{Breeding-genetic potential of Poltava silver rabbit population}

\begin{tabular}{|c|c|c|c|c|c|c|c|c|}
\hline \multirow[t]{2}{*}{ Traits } & \multicolumn{2}{|c|}{$\begin{array}{l}\text { Parental generation } \\
\text { of rabits }\end{array}$} & \multicolumn{4}{|c|}{ Breeding indicators } & \multicolumn{2}{|c|}{ Posterity } \\
\hline & $\begin{array}{l}\text { basic } \\
\text { herd }\end{array}$ & female & $S d$ & $h^{2}$ & $\Delta$ & $S_{t}$ & $\begin{array}{c}\text { perform } \\
\text { ance of } \\
\text { daughters }\end{array}$ & $\begin{array}{c}\text { level of } \\
\text { realization of } \\
\text { genetic } \\
\text { potential, } \%\end{array}$ \\
\hline $\begin{array}{l}\text { Straight body } \\
\text { length, } \mathrm{cm}\end{array}$ & 52,0 & 54,6 & $6^{2,}$ & $\begin{array}{c}0, \\
19 \\
\end{array}$ & $\begin{array}{r}0 \\
49 \\
\end{array}$ & 52,5 & 52,1 & 99,3 \\
\hline Body girth, cm & 24,9 & 26 & $1^{1,}$ & $\begin{array}{l}0 \\
27\end{array}$ & $\begin{array}{l}0 \\
30\end{array}$ & 25,2 & 23,6 & 93,7 \\
\hline Body index,\% & 46,5 & 47,1 & $6^{0,}$ & $2^{0,}$ & $\begin{array}{l}0 \\
12\end{array}$ & 46,6 & 45,2 & 97,1 \\
\hline $\begin{array}{l}\text { Live weight at the } \\
\text { age of } 120 \text { days, } g\end{array}$ & 4450,0 & 4461,9 & $9^{11}$ & 27 & $21^{3}$ & $\begin{array}{l}4453 \\
2\end{array}$ & $\begin{array}{l}4298 \\
6\end{array}$ & 96,5 \\
\hline Width across, cm & 5,7 & 6,1 & $4^{0}$ & $\begin{array}{c}0 \\
52\end{array}$ & $\begin{array}{c}0 \\
21\end{array}$ & 5,9 & 5,9 & 99,8 \\
\hline Fertility, goals & 7,5 & 7,6 & ${ }_{1}^{0}$ & $\begin{array}{c}0 \\
21\end{array}$ & $\begin{array}{c}0 \\
02\end{array}$ & 7,52 & 7,2 & 95,73 \\
\hline
\end{tabular}

It was found that the degree of realization of the genetic potential of rabbits of the breed of rabbits of the Poltava silver breed was $99.3 \%$, the minimum value of this indicator was established among all the studied breeding traits, which is only $93.7 \%$ of the calculated standard for this population. In general, it is worth noting the high level of realization of genetic potential in the created population, which is evidence of optimal interaction of genetic and paratypical factors in the system "genotype-environment".

\section{Conclusions}

The results of the study of exterior indicators of body and live weight of rabbits of the original generation and offspring showed a high level of realization of the genetic potential of animals in the created population - 93.799.9\%, depending on the studied trait. Animals of both generations are characterized by exterior peculiarities of meat and fur. The calculated inheritance coefficients of breeding traits were found to be more probable by the live weight index at the age of 120 days and the width of the lumbar width in adult animals $\left(h^{2}=0.27-0.52, P>0.99 \ldots\right.$ 0.999), which provides the prerequisites for further breeding measures in the direction of increasing meat productivity.

\section{References}

1. Bashchenko, M., Honchar, O., \& Shevchenko, Ye. (2018). Krolivnytstvo - vydannia tretie pereroblene: monohrafiia [Rabbit breeding - third edition revised]. Monograph. Chornobay. [In Ukrainian].

2. Havrysh, O. (2017). Produktyvni yakosti kroliv vitchyznianoi ta zarubizhnoi selektsii za intensyvnoi tekhnolohii vyroshchuvannia [Productive qualities of rabbits of domestic and foreign breeding with intensive cultivation technology]. Effective rabbit breeding and animal husbandry, 3, 14-22. [In Ukrainian].

3. Havrysh, O. (2018). Riven produktyvnosti kroliv riznykh porid ta efektyvnist vykorystannia selektsiinykh indeksiv v krolivnytstvi [Performance level of rabbits of different breeds and efficiency of use of breeding indices in rabbit breeding]. Breeding and genetics of animals, 55, 38-46. [In Ukrainian].

4. Ahmed A. A. Abdel-Wareth, Saskia Kehraus, Abdalla H. H. Ali et al. (2015). Effects of temporary intensive feed restriction on performance, nutrient digestibility and carcass criteria of growing male Californian rabbits, Archives of Animal Nutrition, 69(1), 69-78. doi: 10.1080/1745039X.2014.1002672.

5. Angela Trocino, Elisa Cotozzolo, Cristina Zomeño et al. (2019). Rabbit production and science: the world and Italian scenarios from 1998 to 2018 . Italian J. of Animal Science, 18(1), 1361-1371. doi: 10.1080/1828051X.2019.1662739.

6. Łapa, P., \& Kogut, G. (2019). Porównanie parametrów krzywych wzrostu Richardsa oraz Gompertza u królików rasy nowozelandzkiej białej i kalifornijskiej oraz ich mieszańców [Comparison of parameters of Richards and Gompertz growth curves in New Zealand white and California rabbits and their hybrids]. doi: 10.13140/ RG.2.2.27596.16000. 
7. Honchar, O., Boiko, O., \& Havrysh, O. (2020). Suchasni tendentsii rozvytku krolivnytstva v Ukraini [Current trends in rabbit breeding in Ukraine]. Animal husbandry today, 1, 74-79. [In Ukrainian].

8. Kotsiubenko, H. (2011). Efektyvnist prylyttia krovi porid belhiiskyi veleten ta novozelandska bila pry pokrashchenni produktyvnykh yakostei kroliv porody siryi veleten [Breeding efficiency of breeds of breeds is a Belgian giant and a New Zealand white while improving the productive qualities of the gray giant breed rabbits]. Effective animal husbandry, 8, 44-45. [In Ukrainian].

9. Luchyn, I. S. (2011). Metodychni rekomendatsii shchodo teoretychnykh ta praktychnykh osnov stvorennia i ratsionalnoho vykorystannia vysokoproduktyvnykh populiatsii kroliv [Guidelines on theoretical and practical bases for the creation and rational use of highly productive rabbit populations]. Kolomyia. [In Ukrainian].

10. Sotnichenko, Yu., Bashchenko, M., Boiko, O., Honchar, O., \& Havrysh, O. (2020). Osoblyvosti formuvannia miasnoi produktyvnosti kroliv miaso-shkurkovoho napriamku produktyvnosti. [Features of formation of meat productivity of rabbits of meat and skin direction of productivity]. Effective rabbit breeding and animal husbandry, 6, 117-124. [In Ukrainian].

11. Virág Ács, Katalin Szendrő, Hervé Garreau et al. (2018). Application possibilities of selection indices in Pannon White rabbits' breeding programme. Italian J. of Animal Science, 17(4), 884-889. doi: 10.1080/1828051X.2018.1436007.

12. Metodolohiia ta orhanizatsiia naukovykh doslidzhen u tvarynnytstvi: posibnyk (2017). [Methodology and organization of scientific research in animal husbandry: a guide]. Kyiv. [In Ukrainian].

13. Zubets M. V., \& Basovskyi M. Z. (1995). Pleminna robota: dovidnyk [Breeding work: a handbook]. Kyiv: Assoc. "Ukraine". [In Ukrainian].

14. Plokhynskyi, N. A. (1969). Rukovodstvo po byometryy dlia zootekhnykov [A guide to biometrics for zootechnics]. Moscow: Kolos. [In Russian]. 